\title{
Glorification of Masculinity in the Advertisements of Kool Shaving Cream/Foam: A Critical Discourse Analysis
}

\author{
Md. Mahbubul Alam \\ Lecturer in English \\ Pabna Cadet College, Bangladesh \\ Email: mahbubdell06@gmail.com
}

\begin{abstract}
Advertisement pervades our daily life with strong hold and affects our beliefs and psychological orientation extensively. It is a very effective podium for popularizing products as well as spreading ideologies. Advertisement is one of the dominant platforms of carrying discourses to the masses. The present study is an investigation done from a critical point of view of the advertisements of Kool shaving foam/cream by analyzing the speeches, linguistic and literary devices, character portrayal and physical setting of the advertisements. For the findings, analysis and discussion Critical Discourse Analysis (CDA) based on Fairclough's Three Dimension Approach is applied. The analysis reveals that while circulating and advertising of Kool shaving foam/cream the advertisers have concurrently disseminated patriarchal ideologies and masculine discourses that have long been being lived out in our society as discursive practices. It is also found that at the end of each sample advertisement it is the veneration of masculinity, not the circulation of the product, which is significantly highlighted.
\end{abstract}

Keywords: Advertisement, Kool, masculinity, discourse, Critical Discourse Analysis

\section{INTRODUCTION}

Modern life is notoriously consumed by advertisements. Advertisements have close proximity with our life in respect of representing the socio-cultural values, beliefs and discourses though the representation is not always solid and neutral. It is a strong podium for focusing and spreading any ideology, may the discursive process be done deliberately or inadvertently. Sometimes, it bears distortions or exaggerations; at times, it fuels the fire of socio-cultural disputes like discursive demonstration of the power of masculinity. This paper offers a discussion from a critical standpoint on the advertisements of Kool shaving foam/cream based on the language and contents used there and the socio-cultural ideologies of masculinity reflected through them. The product is owned by the Square Company. It is a renowned group of industries in Bangladesh. This study shows how the advertisements, taken here as the samples, represent the glorification of masculinity through colonizing the minds of the consumers with a view to popularizing their products to the masses. To do so, a Critical
Discourse Analysis based on Fairclough's ThreeDimensional Approach is maintained.

\section{THEORETICAL UNDERPINNINGS OF THE STUDY}

Advertisement

The present era has become product-dominated where the necessity of advertisement is immensely felt. Advertisement is now a very common part of our daily life for its use as the carrier of messages. Sharma (2017) opines that advertisement is the message-carrier of the product, service and image of a company to the consumer (p.343). The use of advertising the products of an organization has multiple reasons, like 'to motivate consumers, to buy goods, or certain consumers not to buy goods, to change attitudes or to encourage retailers to stock produce' (Brierley, 2005, p. 1). Advertisement 'influences our attitudes towards products, companies, brand names, lifestyles and public issues' (Chand \& Chaudhary, 2012, p. 40). Kilbourne (1999) says, 'Advertising is our environment. We swim in it as fish swims in water. We cannot escape it... advertising messages are 
inside our intimate relationships, our homes, our hearts and our heads.' Kilbourne's statement signifies the strong clasp of advertisement with our daily life.

According to Sinclair (1987), the function of advertising includes the creation of opinions, the production of certain roles that viewers take up after their idols and the creation of shared knowledge'. Sinclair also states that advertising not only possesses economic affairs but also it 'closely deals with values, attitudes and ideas shaping culture'. Similarly, Abdelaal \& Sase (2014) opine that the contents of an advertisement are inseparable from culture (p. 254). Supporting them, Chand \& Chaudhary (2012) argue, 'Advertising works not only on a psychological level but also on a cultural one' (p.40). Sharma (2017) states, 'Advertising tries to create a positive attitude towards the brand, the respective offering, and the organization' (p.343). Hence, advertisement has become a pervasive platform for the seller's communication with the buyers with a view to promoting the products. It is very useful for making sound rapport with the consumers.

\section{Gender in Advertisement}

The function of advertising is not only convincing the customer for purchasing the goods, but also 'symbolically defining cultural standards of behavior and relations (Lopukhova, 2015, p. 101)'. Advertisement is not free from spreading discursive agenda that will be discussed in the coming sections. It is a strong platform for presenting and consolidating gender stereotypes. Using gender roles and masculine discourses for promoting products is now very common to the advertisers. Scholars of the disciplines in the behavioral and social sciences have expressed their concerns about social and cultural consequences of advertising, especially, the consequences that have 'significant re-enforcement' of gender stereotypes (Eisend, 2010, p. 418).

Many scholars (Courtney \&Whipple, 1983; Furnham \& Mak, 1999) argue that advertising uses stereotypical gender roles, whereas, some scholars (Ganahl et al. 2003; Milner \& Higgs 2004) say that stereotyping in advertisements is even becoming worse (cited in Eisend, 2010, p. 418). Advertising promotes gender stereotypes that are still in existence in many countries where the campaigns of advertising creates 'gender identity, based on their images, the stereotyped iconography of masculinity and femininity' (Schroeder \& Zwick, 2004). That is why Gentry \& Harrison (2010) argue that, 'it is important to critically examine the discursive frameworks that shape our understanding of such topics' (p. 90). Advertisement is, Pollay (1986) opines, 'systematically accused of perpetuating excessively restrictive, degrading and even false stereotypes (cited in Vela, Romero \& Giner, 2006, p.84)'. Hence, as a powerful text of communicating discursive massages, the function of advertisement is never value-free; rather, it is value-laden impacting gender ideology massively.

\section{Traits of Masculinity}

The ideation of 'gender' is socially constructed. Likewise, the concept of 'masculinity' is watery and unstable as this is also a social construct and it manifests differently in various cultures and societies with its pervasive and discursive presence. But, the point is that, as Connell (2005) states, 'All societies have cultural accounts of gender, but not all have the concept masculinity' (p.67). She also opines that masculinity can be understood as contrast to femininity (p.68). ItuluaAbumere (2013) argues that, 'Masculinity consists of those behaviors, languages and practices, existing in specific cultural and organizational locations, which are commonly associated with males' (p. 42). She also argues that "masculinity exist as both a positive, in as much as they offer some means of identity significations for males, and as a negative, in as much as they are not the Other'(Feminine) (p.42).

Masculine attributes may differ from culture to culture and society to society. But, their basic point of distinction is almost same. Usually, male attributes in traditional concept are related to dominance, stoicism and rationality in contrast to the female attributes like being submissive, passive and irrational (Bozkurta, Tartanoglub \& Dawesc, 2015, p. 255). Referring to the context of the 
countries like the USA, Australia and Turkey they state that masculinity is often associated with 'independence, physical strength, aggressiveness, competitiveness, objectivity, rationality and showing less emotion than their female counterparts (p. 255)'. Masculine identity also signifies those essential tenets like 'toughness, dominance, and readiness" that used to "settle conflicts through violence' (Krienert, 2003; cited in Bozkurta, Tartanoglub \& Dawesc, 2015, p. 256). Fighting is another masculine identity that is socially and culturally endorsed (Kimmel, 2004; cited in Bozkurta, Tartanoglub \& Dawesc, 2015, p. 256). Kaufman (1987) opines that masculinity signifies 'reaction against passivity, powerlessness and repression against all desires and traits that are treated negatively in a particular society' ( $p$. 11).

The socialization process makes the society believe that boys are expected to be 'real man' and ready to take risk and show bravery (Bozkurta, Tartanoglub \& Dawesc, 2015, p. 256). Violence and aggressiveness are not the only masculine features; rather, men's response 'tends to be primarily physical' and they are used to resolve 'debates, differences, confrontations, and personal affronts through physical means (Soulliere, 2006, p.5)'. Winning and achievement form one of the basic identities of a man (p.6). The significance of masculinity goes with the process of how to become a master of women', and showing violence is an 'accepted and dominant way of being a man' (Khan \& Khandaker, 2017, p. 261). Men tend to be 'the protector of women and children (Abbott, 2000; cited in Khan \& Khandaker, 2017, p. 260). On the other hand, women tend to be 'passive and dominated by men" and these are "the typical portrayals of femininity' (Horowitz \& Kaufman, 1987, p. 86).

\section{Discourse and Critical Discourse Analysis}

Discourse is, as Sipra (2013) observes, 'the speech patterns and usage of language, dialects, and acceptable statements, within a community' and it is so powerful that it can influence in producing and reproducing 'unequal power relations between different ethnicities, social classes, genders, ages, and professional groups' (p. 27).
Discourse 'allows us to understand what the object is about and a process of delimitation from other objects' (Shaikh et al, 2015, p.113). According to Mithun (2015), 'discourse is more than an autonomous level beyond the sentence. Grammar provides speakers with tools for packaging information. And how information is packaged depends on the larger discourse context, the flow of thought through time, the communicative and social goals of the speaker, the presumed knowledge state of the audience, and more' (p.12). Gee (1999) states that discourse makes rapport between texts and specific social practices. Norman Fairclough is of the opinion that while selecting discourses there are some essential 'assumptions' which are never 'value-free and innocent', rather, they are 'ideologically driven and motivated', thus, 'discursive practices may have ideological effects since they can produce and reproduce unequal power relations between social classes, gender groups and ethnic and cultural majorities and minorities through the ways they represent things and position people' (Amoussou \& Allagbe, 2018, p.14).

Advertisement is a powerful discourse which 'may employ social power abuse, dominance, and inequality, and eventually change and maintain social practices' (Tahmasbi \& Kalkhajeh, 2013, p.126). 'The study of discourse and gender is an interdisciplinary endeavor undertaken by scholars in linguistics, anthropology, communications, social psychology, education, literature, and other disciplines' (Kendall \& Tannen, 2015, p.640).

Critical Discourse Analysis (CDA) is the study of the relationship between discourse and power. It is an inter-disciplinary approach put forward in the early 1990s by some scholars such as Theo van Leeuwen, Gunther Kress, Teun van Dijk, and Norman Fairclough (Wodak \& Meyer, 2001) and many 'historians, business institutions, lawyers, politicians, etc., to investigate social problems relating to their work' (Bloor \& Bloor, 2007). Rahimi \& Sharififar (2015) argue that CDA attempts to unveil 'hidden ideological and power relations which are embedded in text' (p.504) and establishes the channel in between microlevel, the text and mesolevel, discursive practice (p.505). Van Dijk opines that a CDA analyst keeps objective 
stance from his analysis and his aim is to 'expose the social and political inequality in order to change it with social justice and equality in economics as well as politics for different sections of the society' (1989). Similarly, Wodak (1992) states that, the prime target of CDA is to 'unmask hidden ideologies and also unclear power structure, dominance, and political control in language in use' (p.8).

Critical Discourse Analysis builds an affinity between language and power through focusing on 'social problems, and especially on the role of discourse in the production and reproduction of power abuse or domination' (van Dijk, 2001, p.96). Wodak (2001) sttates that CDA analyzes opaque as well as transparent structural relationships of dominance, discrimination, power and control as manifested in language. CDA possesses some linguistic techniques that unearth language's relationship with power, politics, society and identity (Corson, 1995).

Rogers (2004) argues that CDA deals with not only describing and interpreting discourse in context, but also explains why and how discourses operate (p.03). CDA, as Van Dijk (2003) observes, explores critically 'the way social power abuse, dominance and inequality are enacted, reproduced, and resisted by text and talk in the social and political context'. We shall put forward a broad definition of CDA offered by Fairclough (1995): 'By critical discourse analysis I mean analysis which aims to systematically explore often opaque relationships of causality and determination between (a) discursive practices, events and texts, and (b) wider social and cultural structures, relations and processes; to investigate how such practices, events and texts arise out of and are ideologically shaped by relations of power and struggles over power, and to explore how the opacity of these relationships between discourse and society is itself a factor securing power and hegemony (p.135).'

Van Dijk (1995) shares that while working in CDA some criteria should be kept in mind: a) CDA is problem-oriented which deals with studying racism, sexism, colonialism and other forms of social inequality; b) CDA is a critical approach of studying text and talk; c) CDA focuses on the relation between discourse and society; d) CDA deals with all levels and dimensions of discoursephonology, syntax, semantics, style, rhetoric, speech acts, pragmatic strategies, and other semiotic dimensions like picture, film, music, sound and gestures; e) CDA focuses on the underlying ideologies and relations of class, gender, ethnicity, race, language, religion, age, sexual orientation, power, dominance and inequality and the ways these are produced and resisted by social groups via texts and talks (p. 17).

\section{Fairclough's Three Dimension Framework}

According to Fairclough (1993), every discursive event possesses three dimensions or facets: it is a spoken or written language text (image, speech, writing or combination of these), it is an example of discursive practice (production, consumption and distribution of the text) and it is a piece of social practice (p.136). Corresponding to the three levels of discourse, he suggests three stages of Critical Discourse Analysis: description, interpretation and explanation, each having connection with others i.e. textual, interpretational and social levels of CDA (1992). In the first stage (Description), personal experience and knowledge of the speaker or the writer is described. Here, the text is the object. This is the linguistic description (vocabulary, grammar and text structure) at the formal level of the text.

In the second stage (Interpretation), the relationship between the discursive processes and the text is interpreted. Fairclough views 'interpretation is concerned with the relationship between text and interaction with seeing the text as the product of a process of production, and as recourse in the process of interpretation' (1992). In this stage, relationship between discourse and its production and consumption is interpreted. Besides, in this stage 'discourse is not only regarded as text but also a discursive practice in this stage, which means apart from analyzing linguistic features and text structure, attention should be drawn to other factors such as speech act and intertextuality... In other words, this step deals with the exploration of inter-textual relations 
among discourse, texts and setting.' (Handayani, Heriyanto\& Soemantri, 2018, p.339).

In the third stage, social practice (Explanation), the relationship between discourse and socio-cultural reality is analyzed. Fairclough opines that, 'Explanation is concerned with the relationship between interaction and social context with the social determination of the process of production and interpretation, and their social effects' (1993). The analysis in this stage is done 'in reference to the historical, social, and cultural Contexts' and 'factors like ideology or power are taken into account so as to fully explain the interaction between social-cultural context and then production and consumption of texts' (Handayani, Heriyanto \& Soemantri, 2018, p.339).

\section{Objectives of the Study}

The objective of the study is to show how the power of masculinity is focused and glorified in the advertisements of Kool Shaving Cream/Foam.

\section{Methodology}

This study is based on the analysis of the advertisements of Kool Shaving Cream. As the method of research is purely analytical, qualitative technique has been adopted to interpret the data. Three distinct video clips of the advertisements of Kool Shaving Cream are taken as samples in this research. The videos are retrieved from the YouTube. The interpretation and analysis is done by employing the three-dimensional framework put forward by Norman Fairclough.

\section{Abbreviation}

SA- $1=1^{\text {st }}$ Sample Advertisement

(Available at-

https://www.youtube.com/watch?v=owY6wTqTw

$\underline{\mathrm{HI}})$

SA $-2=2^{\text {nd }}$ Sample Advertisement
(Available at-

https://www.youtube.com/watch?v=-c20fJqKWhg)

SA $-3=3^{\text {rd }}$ Sample Advertisement

(Available at-

https://www.youtube.com/watch?v=1zPaLoonqa0)

\section{Analysis and Discussion}

\subsection{Dimension-1: Textual Analysis}

A text does consist of not only linguistic units; it may also be multi-modal like visual, audio, gestural, spatial etc. (movies, advertisements, books, emails, messages, songs etc). Text analysis consists of analyzing lexical choices, cohesion, coherence as well as stylistic features like narrative viewpoint, structure of stanzas, juxtaposition that 'focuses on the particular theme and broader sociopolitical perspective of the speaker' (Sipra, 2013, p.30).

In the $1^{\text {st }}$ sample advertisement (SA-1), the initial part occurs at a hair salon where the barber shaves the beard of a smart young man. The second part consists of another young man who attempts to win the heart of a girl by force and finally restrained by the first young man. The third part is about the Kool shaving foam, where a background voice is used. The $2^{\text {nd }}$ sample advertisement (SA-2), starts with a wrestler (model Nobel) who is defeated in the match. But, he is determined to fight another match in spite of his wife's and the coach's warning. At last, he wins. Before starting the wining-match he uses Kool shaving cream. The $3^{\text {rd }}$ sample advertisement (SA3) starts with cricketer Mashrafe showing how struggle he has faced all through his career. He suggests his team-mates (Miraz as the representative) to use Kool shaving foam as a part of ensuring success in cricket.

In the table below a brief presentation of textual information of the sample videos is given.

Table-1: Textual Analysis

\begin{tabular}{|l|l|l|l|}
\hline \multirow{2}{*}{$\begin{array}{l}\text { Textual } \\
\text { information }\end{array}$} & Example & \multicolumn{2}{|c|}{ SA-3 } \\
\cline { 2 - 4 } & SA-1 & SA-2 & 36 seconds \\
\hline Length & 40 seconds & 50 seconds & Slow move and more \\
\hline Camera style & Speedy moves, more close-up & Speedy moves, more & .
\end{tabular}


LANGUAGE CIRCLE: Journal of Language and Literature, 16(1) October 2021

\begin{tabular}{|c|c|c|c|}
\hline & shots & distant shots & distant shots \\
\hline Video contents & $\begin{array}{l}\text { Other objects along with } \\
\text { people }\end{array}$ & $\begin{array}{l}\text { Other objects along } \\
\text { with people }\end{array}$ & $\begin{array}{l}\text { People are focused, } \\
\text { no background } \\
\text { objects }\end{array}$ \\
\hline $\begin{array}{l}\text { Use of light \& } \\
\text { color }\end{array}$ & $\begin{array}{l}\text { Dominance of dim light on the } \\
\text { background; brightness at the } \\
\text { last portion }\end{array}$ & $\begin{array}{lrr}\begin{array}{l}\text { Planned mixing } \\
\text { dimness }\end{array} & \text { and } \\
\text { brightness } & & \\
\end{array}$ & $\begin{array}{l}\text { Brighter and } \\
\text { dominance of } \\
\text { whiteness } \\
\end{array}$ \\
\hline Slogan & 'For The Real Man' & 'SPIRIT WITHIN' & 'For The Real Man' \\
\hline Target audience & Average male group & Average male group & Average male group \\
\hline Repetition & $\begin{array}{l}\text { - repetition of 'jor' (enforce) } \\
\text { and 'real' }\end{array}$ & $\begin{array}{l}\text { Repeated use of the } \\
\text { word 'challenge' }\end{array}$ & $\begin{array}{l}\text { Repeated use of the } \\
\text { word 'struggle' }\end{array}$ \\
\hline Contrast & $\begin{array}{l}\text {-'jor' (enforce) vs. "smooth" } \\
\text {-Clean shaved boy vs. the } \\
\text { unshaved one }\end{array}$ & $\begin{array}{l}\text { Confident wrestler vs. } \\
\text { mentally weak coach } \\
\text { and lady }\end{array}$ & \\
\hline Symbol \&motif & White color, knife & \begin{tabular}{|l|} 
White color \\
\end{tabular} & White color \\
\hline Imperatives & $\begin{array}{l}\text { 'Tumi ekkhon jaba mane } \\
\text { ekkhon jaba' (Come with me } \\
\text { right now) } \\
\text {-'Apni jan' (You go) }\end{array}$ & "Stand up" & $\begin{array}{l}\text {-'Khudro jontrona agei } \\
\text { biday koro'(Vanish } \\
\text { minor hassles first) } \\
\text {-'Tule nao Kool and } \\
\text { face the world...' }\end{array}$ \\
\hline Foreshadowing & $\begin{array}{l}\text { The background song } \\
\text { 'Jor kore mon pawa jay ki?' (Who } \\
\text { can win heart by force?) }\end{array}$ & & 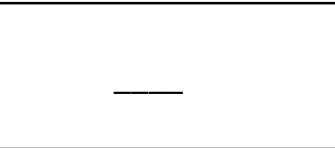 \\
\hline $\begin{array}{l}\text { Significant } \\
\text { phrases/dictions }\end{array}$ & $\begin{array}{l}\text { Jor (enforce), smooth, ultra } \\
\text { gliding, real man }\end{array}$ & $\begin{array}{l}\text { Stronger, faster, } \\
\text { challenge, fight, spirit, } \\
\text { man, lorte hobe arekbar } \\
\text { (need to fight again) }\end{array}$ & $\begin{array}{l}\text { Purusher struggle } \\
\text { (Man's struggle),boro } \\
\text { safollo (greater } \\
\text { success), face the } \\
\text { world, real man }\end{array}$ \\
\hline $\begin{array}{l}\text { Use of informal } \\
\text { language }\end{array}$ & $\begin{array}{l}\text { Ei! (hello!), shunba (will listen), } \\
\text { ekkhon jaba (Come with me } \\
\text { right now) }\end{array}$ & 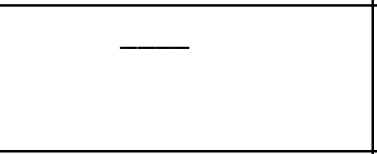 & - \\
\hline Adjective & Real, smooth & $\begin{array}{l}\text { Stronger, faster, best } \\
\text { (newspaper image) }\end{array}$ & Real \\
\hline Simile/ metaphor & 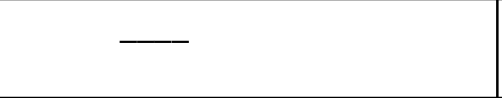 & - & $\begin{array}{l}\text { Face the world like a } \\
\text { real man }\end{array}$ \\
\hline Background voice & Male (including the singer) & Male & Male \\
\hline
\end{tabular}

The slogans of the advertisements help maintain proximity with the consumer (male) of the product since the target audience is the male group. Use of light and color is significant. In each advertisement we see the use of brighter light with extra whiteness when Kool shaving foam/cream appears, to connect a corresponding relationship with the brightness of the face after shaving with Kool. It becomes relevant when we see the use of the word 'smooth' by the background voice. White color works here as a motif, being used recurrently. Use of informal language by one of the speakers in the SA-1 helps the advertiser create intimacy with the consumer. Background voice of the advertisements, including the music of SA-1 is given by a male. There is repetition of the words 'enforce', 'real', 'struggle' and 'challenge'. These words are 
repeated to glorify the masculine vigor in the advertisement. Both of the issues establish connection between the product and the gender of the consumer that will be further discussed in the third dimension of CDA in this paper.

6.2 Dimension-2: Interpretation (Discursive Practice)

In this dimension it is shown how power relations are established through text. This level of analysis involves analyzing the text's production, distribution and consumptions. Here, how the advertiser uses various strategies in the advertisement to convince the consumer is examined.

In the table below a brief presentation of the strategies used by the advertisers in the sample videos is given.

Table-2: Interpretation

\begin{tabular}{|l|l|l|l|}
\hline \multicolumn{1}{|c|}{ Strategy } & \multicolumn{3}{|c|}{ Example } \\
\hline Celebrity endorsement & \multicolumn{1}{|c|}{ SA-1 } & \multicolumn{1}{c|}{ SA-2 } & \multicolumn{1}{c|}{ SA-3 } \\
\hline $\begin{array}{l}\text { Code-switching/ } \\
\text { Code- mixing }\end{array}$ & $\begin{array}{l}\text {-'No jor jobordosti' } \\
\text {-'Real man kokhono jor } \\
\text { khatay na' }\end{array}$ & $\begin{array}{l}\text { Uses famous model } \\
\text { and actor Nobel }\end{array}$ & $\begin{array}{l}\text { Uses the cricketers } \\
\text { 'I have to fight' } \\
\text { Mashrafe and Miraz }\end{array}$ \\
\hline Emotive words/ phrases & $\begin{array}{l}\text {-Ultra gliding } \\
\text {-smooth }\end{array}$ & $\begin{array}{l}\text { 'Purusher struggle hobe } \\
\text { boro boro' }\end{array}$ \\
\hline Invoking inadequacy & $\begin{array}{l}\text { Rejecting normal foams } \\
\text { by the barber }\end{array}$ & - & $\begin{array}{l}\text {-Khudro jontrona } \\
\text {-Real man }\end{array}$ \\
\hline Comparing & $\begin{array}{l}\text { Normal shaving foam } \\
\text { vs. Kool shaving foam. }\end{array}$ & - & $\begin{array}{l}\text { 'Sadharon foam chere tule } \\
\text { nao Kool.' }\end{array}$ \\
\hline
\end{tabular}

In SA-2 and SA-3, three prominent celebrities Nobel, Mashrafe and Miraz are the central figures. It means that the advertisers have used the celebrities for their approval of the product Kool shaving cream/foam to the common people/consumers. This is an effective emotional strategy to reach the mind of the consumer because if a celebrity, for example cricketer Mashrafe, certifies a product, it gets instant place in the mind of the common people. Use of codeswitching/mixing creates the advertiser's intimacy with the consumer because codeswitching/mixing is a frequently occurred phenomenon in our daily speaking. As through code-switching/mixing the speaker maintains informal linguistic approach to the listener, the advertiser reaches and convinces the consumer with less difficult efforts.

The advertisers have resorted to a technique of comparison where they show that only Kool shaving foam is effective by showing all other shaving foams ineffectual. In SA-1, the barber attempts to use normal shaving foam, but instantly realizing his mistake he takes Kool shaving foam. In SA-3, the background speaker says: 'Shaving-e irritation aar rash sristykari sadharon foam chere tule nao Kool'. Through comparison the advertiser points at the inadequacy of all other shaving foam and tries to persuade the audience to use Kool which is focused as 'smooth' and the best.

\subsection{Dimesion-3: Social Analysis}

This part will focus on how the advertisers, purposely or inadvertently, have glorified masculinity in the name of popularizing their product Kool shaving foam/cream.

The slogan of SA-1 and SA-3 is 'Kool Shaving Foam for the Real Man'. The concept of 'real man' is stereotypical. The "real man" is the ultimate 
winner and the central figure. The advertiser has focused the first young man in SA-1as the 'real man'. Actually, this is the man who wins the heart of the girl, the girl who was about to be fallen to prey by the second young man. The second man tries to win her by force and later restrained by the 'real man'. The second young man shows aggressiveness and applies force to win the heart of the girl by saying: 'Tumi ekkhon jaba mane ekkhon jaba' (Come with me right now). He resorts to dominance and violence to succeed in the endeavor which is a major masculine tenet in our society. The boy is presented as tough using physical strength to win over his female counterpart. The girl expresses her defenselessness and powerlessness. In this way, a relationship of binary opposition, strength vs. vulnerability, is carefully established to show the demarcation between the power of man and the weakness of woman. Even the smart young man who rescues the scared girl uses the male mechanism of order and dominance when he says to her: 'Apni jaan' (you go) and thus he becomes the 'master of woman'.

The background song in SA-1 'jor kore mon paowa jay ki?' (Who can win heart by force?) connotes positive message and states that no one can win someone's heart by force. It works as a foreshadowing as just after the moment we can see the triangle episode consisting of the girl. The young man who tries to win the girl ultimately fails and the first young man coming from the barber shop restrains the second man by using charismatic touch and words: 'Vai, jor kore ki prem hoy?' (Brother, can you get her consent by force?). It works magically to the girl and consequently, a soft sensation works inside her. Here, the rescuer young man is presented as possessing charismatic power of resolution and the girl is shown again as relying on the male counterpart. Therefore, the advertisement attempts to demonstrate that man is the ultimate source of reliance and solution and woman is always vulnerable to collapse.

The same binary opposition we see in SA-2 where the husband (model and actor Nobel) is presented as possessing Herculean qualities like taking challenge, being confident and having valor whereas, the wife is focused as having no confidence and zeal of gallantry. The man is defeated in wrestling but he wants to 'fight again' because he loves 'challenge'. But the wife tries to restrain him by saying: 'Tumi ki pagol hoye geso? Jano er porinam?' (Have you gone mad? Don't you know its consequence?). It signifies that woman has no spirit of confidence, competitiveness and taking challenge. Love for competitiveness and challenge is a masculine quality which the society expects. This is clearly mirrored through the portrayal of binary opposition of the husband and the wife. The headline of the newspaper, read by the husband, written as ' $I$ ' $m$ the best' consisting of the image of the winner wrestler is used as a symbol of strong masculine discourse. In the newspaper the image of the wrestler showing muscle signifies the glorified manifestation of masculine appearance and physical strength. The husband's utterance 'I've to fight because I'm a man' is very significant to study our socio-cultural beliefs about masculine trait- a man must keep on fighting until the desired success comes.

Masculine discourses are also used in SA-3. The central figure of the advertisement Mashrafi through a secondary voice states: 'Purusher struggle hobe boro boro' (Man's struggle will be for greater causes). It clearly shows our society's outlook on man's ability and mythic power. Our society has bestowed almost mythic capability to the man to such a extent that a man has no time for dealing with Khudro jontrona (minor hassles), rather his whole life will be spent for constant fighting and solving greater problems to 'face the world like a real man'. In SA-2 wrestling is used as a symbol of masculinity. Wrestling symbolizes man's readiness for taking risk and showing bravery. The wife is shown as the only active spectator who reacts painfully while seeing her husband's falling down. Her scared and sorrowful reaction indicates woman's incapability for enduring toughness and facing danger.

\section{CONCLUSION}

As a genre advertisement is one of the powerful platforms of carrying discourses to the mass 
people. The advertisements of Kool shaving foam/cream bear masculine discourses that are clearly based on gender bias. In the third dimension of Critical Discourse Analysis the manifestation of gender bias is studied with available examples in those advertisements. In the first two dimensions of Critical Discourse Analysis this paper has also gone through analyzing discourses on the basis of the mechanical and textual realities of the advertisements, though within a limited space. The analysis shows that the advertisers in the process of circulating and popularizing their product, Kool shaving foam/cream, have maintained a binary presentation of man and woman through speech, linguistic and literary devices, character portrayal and physical setting.

\section{REFERENCES}

Abdelaal, N. M. \& Sase, A. S. (2014). Advertisement analysis: A comparative critical study.

Advances in Language and Literary Studies, 5 (6), 254-259. Retrieved from https://www.journals.aiac.org.au/index.php/ alls/article/view/601

Amoussou, F. \& Allagbe, A. (2018). Principles, theories and approaches to critical discourse analysis. IJSELL, 6(1), 11-18. Retrieved from http://dx.doi.org/10.20431/2347-3134.0601002

Bloor, M. \& Bloor, T. (2007). The practice of CDA: An introduction. Hodder Education.

Bozkurta, V., Tartanoglub, S. \& Dawesc, G. (2015). Masculinity and violence: sex roles and violence endorsement among university students. Procedia- Social and Behavioral Sciences, 205, 254 - 260. Retrieved from https://doi.org/10.1016/j.sbspro.2015.09.072

Brierley, S. (2005). The advertising handbook. Routledge.

Chand, P. \& Chaudhary, S. (2012). Advertising discourse: Studying creation and perception of meaning. International Journal of English and Literature, 3(2), 40-49. DOI: 10.5897/IJEL11.070

Connell, R. W. (2005). Masculinities. University of California Press.
Corson, D. (1995). Discourse and power in educational organizations. Hampton Press.

Eisend, M. (2010). A meta-analysis of gender roles in advertising. Journal of the Academy of Marketing Science, 38, 418-440. Retrieved from https://doi.org/10.1007/s11747-009-0181$x$

Fairclough, N. (1992). Discourse and social change. Polity Press.

Fairclough, N. (1993). Critical discourse analysis and the marketization of public discourse: The universities. Discourse and Society, 4(2), 133-168. DOI: $10.1177 / 0957926593004002002$

Gee, J.P. (1999). An introduction to discourse analysis: Theory and method. Routledge.

Gentry, J., \& Harrison, R. (2010). Is advertising a barrier to male movement toward gender change? Marketing Theory, 10(1), 74-96. DOI: 10.1177/1470593109355246

Handayani, D., Heriyanto, \& Soemantri, Y. (2018). Fairclough's three dimension framework used on Trump's political speech: A critical discourse analysis (A case study of historic speech related to Jerussalem as Israel's capital), Proceedings of the 1st Annual International Conference on Language and Literature, 18-19 April 2018, Fakultas Sastra, UISU, Medan, Indonesia.336-343. DOI: 10.30743/aicll.v1i1.42

Hassan et al. (2019). An Application of Fairclough's three dimensional CDA approach to Fraser Anning's speech in Australian senate. Linguistic Forum, 1(1), 01$09 . \quad$ Retrieved from http://linguisticforum.com/index.php/ling/art icle/view/5

Itulua-Abumere, F. (2013). Understanding men and masculinity in modern society. Open Journal of Social Science Research, 1(2):42-45. DOI: 10.12966/ojssr.05.05.2013

Kaufman, M. (1987). The construction of masculinity and the triad of men's violence. In M.

Kaufman (Ed.), Beyond patriarchy: Essays by men on pleasure, power and change (pp. 1-29). Oxford University Press.

Kendall, S. \& Tannen, D. (2015). Discourse and Gender. In D. Tannen, H. E. Hamilton, \& D. 
Schiffrin (Ed.), The Handbook of Discourse Analysis (pp. 639-660). Bloomsbury Publishing Plc.

Khan, A. R., \& Khandaker, S. (2017). Analysing masculinity from the key theoretical lenses and searching for linkages with violence against women. Masculinities and Social Chang, 6(3), 257-287. DOI: http://dx.doi.org/10.17583/mcs.2017.2593

Kilbourne, J. (1999). Can't buy my love: How advertising changes the way we think and feel. Simon and Schuster.

Lopukhova, O.G. (2015). The impact of gender images in commercials on the selfconsciousness of adolescents. Psychology in Russia: State of the Art, 8(1), 100-111. DOI: 10.11621/pir.2015.0109

Mithun, M. (2015). Discourse and Grammar. In D. Tannen, H. E. Hamilton, \& D. Schiffrin (Ed.), The handbook of discourse analysis (pp. 1141). Bloomsbury Publishing Plc.

Rahimi, E. \& Sharififar, M. (2015). Critical discourse analysis and its implication in English language teaching: A case study of political text. Theory and Practice in Language Studies, 5(3), 504-511. DOI: http://dx.doi.org/10.17507/tpls.0503.08

Rogers, R. (2004). An introduction to critical discourse analysis in education. Lawrence Erlbaum Associates, Inc.

Schroeder, J.E., \& Zwick, D. (2004). Mirrors of masculinity: Representation and identity in advertising images. Consumption, Markets and Culture, 7, 21-52. DOI: $10.1080 / 1025386042000212383$

Shaikh, M. et al. (2015). The representation of men and women in advertisements: A critical discourse analysis. The Women-Annual Research Journal, 7, 109-141. Retrieved from https://www.researchgate.net/publication/28 1237934_THE_REPRESENTATION_OF_ME N_AND_WOMEN_IN_ADVERTISEMENTS _A_CRITICAL_DISCOURSE_ANALYSIS

Sharma, R. (2017). Interrelation between culture and advertising art. International Journal of Science, Technology and Management, 6(5), 341-349.

Retrieved

from http://www.ijstm.com/currentissue.php?id=1 03

Sinclair, J. (1987). Images incorporated: Advertising as industry and ideology. Croom Helm.

Sipra, M. A. (2013). Critical discourse analysis of Martin Luther King's speech in sociopolitical perspective, Advances in Language and Literary Studies, 4(1), 27-33. DOI: 10.7575/aiac.alls.v.4n.1p.27

Soulliere, D. M. (2006). Wrestling with masculinity: Messages about manhood in the WWE.

Sex Roles, 55, 1-11. Retrieved from https://doi.org/10.1007/s11199-006-9055-6

Tahmasbi, S. \& Kalkhajeh, S.(2013). Critical discourse analysis: Iranian banks advertisements.

Asian Economic and Financial Review, 3(1), 124145. Retrieved from http://www.aessweb.com/download.php?id= 1716

Van Dijk, T. A. (1989). A handbook of discourse analysis. Academic Press Limited.

Van Dijk, T.A. (1995). Aims of critical discourse analysis. Japanese Discourse, 1, 17-27.

Van Dijk,T., A. (2001). Multidisciplinary critical discourse analysis: A plea for diversity. Sage. Van Dijk, T. . (2003). Critical discourse analysis. In D. Schiffrin, D. Tannen, \& H. E. Hamilton (ed), The Handbook of discourse analysis (pp. 352-371). Blackwell.

Vela, M. R., Romero, M. J. \& Giner, E.C. (2006). Advertising content as a socialization agent: potential reinforcement of gender stereotypes. ESIC MARKET, Sep-Dec, 81-105. Retrieved from https://www.esic.edu/editorial/editorial_revi sta_esic_contenidos.php?id=166\&lm $=\mathrm{i}$

Wodak, R. (1992). The discursive construction of national identity. In: Wodak R. et al. (Ed.), The discursive construction of national identity (pp. 7-10). Edinburgh.

Wodak, R. \& Meyer, M. (2001). Methods of critical discourse analysis. Sage.

Wodak, R. (2001). What critical discourse analysis is about-a summary of its history, important 
\& M. Meyer (eds.), Methods of Critical Discourse Analysis (pp. 1-13). Sage. 